Яровой Тихон Сергійович кандидат наук з державного управління, доцент, доцент кафедри публічного адміністрування Міжрегіональної Академії управління персоналом, вул. Фрометівська, 2, м. Київ, 03039, тел.: (066) 017-92-16, e-mail: tikhon_9563963@ukr.net, https://orcid.org/0000-0002-7266-3829

Науменко Костянтин Валерійович аспірант кафедри публічного адміністрування Міжрегіональної Академії управління персоналом, вул. Фрометівська, 2, м. Київ, 03039, тел.: (067) 161-98-23, e-mail: k.v.naumenko@i.ua, https://orcid.org/0000-0001-8822-3070

\title{
АНАЛІЗ ШЛЯХІВ ЗАБЕЗПЕЧЕННЯ ПОДАТКОВОЇ БЕЗПЕКИ ДЕРЖАВИ
}

Анотація. У статті розглянуто шляхи забезпечення податкової безпеки в системі міжнародної економічної безпеки, в умовах загроз, ризиків та небезпек. Вивчено різні підходи до підтримки оптимального балансу між податковим навантаженням, та інвестиційною привабливістю бізнесу. Було проведено аналіз ключових проблем, що створюють перешкоди на шляху до оптимізації податної системи зокрема та економічної безпеки держави в цілому.

На основі аналізу запропоновано шляхи їх вирішення за допомогою спільного регулювання фінансових відносин, що здійснюється на глобальному i регіональному рівнях. 3 метою встановлення рівня податкової безпеки країни, досліджено показники, які на думку автора $є$ інформативними для таких задач.

Розглядаються різні підходи до розуміння податкової безпеки, як складкової економічної безпеки держави, що дозволило визначити роль і місце цього поняття в державному управлінні. Разом з тим, оскільки теоретико-методологічний апарат, що застосовується на сьогоднішній день в системі забезпечення безпеки держави не включає в себе понять пов'язаних із податкової безпеки, у статті було представлено концепцію забезпечення економічної безпеки держави, 3 урахуванням оптимізації фіскальної політики.

Основні підходи до забезпечення економічної безпеки держави, шляхом оптимізації податкової безпеки, висвітлюються у статті, як комплекс заходів спрямований на: отримання точної інформації стосовно поточного стану податкового навантаження на бізнес; визначення оптимальних заходів, щодо інвестиційного стимулювання 3 використанням варіантів окремих податкових спрощень; розробки механізмів мінімізації ухилень від сплати податків; творення єдиної інформаційної площадки для взаємодії представників бізнесу та представників податкових органів. Все це, а також інші аспекти висвітлено у статті, як комплекс рекомендацій для покращення рівня податкової безпеки.

Ключові слова: податкова безпека, державне управління, аналіз, шляхи забезпечення, податки, економіка, держава, громадяни. 
Yarovoi Tikhon Serhiiovych Candidate of Sciences in Public Administration, Associate Professor, of the Interregional Academy of Personnel Management, Frometivska str., 2, Kyiv, 03039, tel.: (066) 017-92-16, e-mail: tikhon_9563963@ukr.net, https// orcid.org/0000-0002-7266-3829

Naumenko Kostiantyn Valeriiovych graduate student of the Department of Public Administration of the Interregional Academy of Personnel Management, Frometivska str., 2, Kyiv, 03039, tel.: (067) 161-98-23, e-mail: k.v.naumenko@i.ua, https //orcid.org / 0000-0001-8822-3070

\section{ANALYSIS OF WAYS TO ENSURE THE STATE TAX SECURITY}

Abstract. The article considers the ways of ensuring tax security in the system of international economic security, in the conditions of threats, risks and dangers. Different approaches to maintaining the optimal balance between the tax burden and the investment attractiveness of the business have been studied. An analysis of key issues that create obstacles to optimizing the tax system in particular and the economic security of the state as a whole was conducted.

Based on the analysis, ways to solve them through joint regulation of financial relations, carried out at the global and regional levels. In order to establish the level of tax security of the country, the indicators were studied, which in the author's opinion are informative for such tasks.

Different approaches to the understanding of tax security as a folding economic security of the state are considered, which allowed to determine the role and place of this concept in public administration. However, since the theoretical and methodological apparatus used today in the system of state security does not include concepts related to tax security, the article presented the concept of economic security of the state, taking into account the optimization of fiscal policy.

The main approaches to ensuring the economic security of the state, by optimizing tax security, are highlighted in the article as a set of measures aimed at: obtaining accurate information about the current state of the tax burden on business; determination of optimal measures for investment incentives using the options of individual tax simplifications; development of mechanisms to minimize tax evasion; creation of a single information platform for interaction between business representatives and representatives of tax authorities. All this, as well as other aspects, are covered in the article as a set of recommendations for improving the level of tax security.

Keywords: tax security, public administration, analysis, ways of providing, taxes, economy, state, citizens.

Постановка проблеми. На сьогоднішній день, питання побудови оптимальної податкової політики не просто формують рівень інвестицій в економіку країни, а й носять стратегічний характер для державної безпеки, економічної безпеки та ряду інших складових, які характеризують стан захищеності нашої країни. 
В таких умовах, форми та методи забезпечення державної безпеки в багатьох випадках залежать від фіскальної політики, їі направленості на оптимізацію податкових відносин, відкритості податкових органів перед платниками податків.

Разом 3 тим, швидкі зміни в нормативних документах податкової системи України, інфляційні процеси, віддаленість представників податкових органів від бізнесу, відсутність ефективних заходів для стимулювання та розвитку малого бізнесу (податкових канікул, спрощення системи оподаткування, тощо), а також багато інших не вирішених питань, спричиняють такі негативні явища, як: ухилення від оподаткування, відтік капіталів в офшори, збільшення частки тіньової економіки, перекладання основного податкового тягаря на плечі законослухняних платників.

Для вирішення цих пролем, потрібно кардинально змінювати підходи до оподаткування, які на сьогоднішній день, в основному представлені у контексті саме фіскальних заходів, а не таких, що спрямовані на стимулювання економічного розвитку. Останній варіант, може бути стимулом для збільшення підприємницької активності в країні, а також залучення іноземних інвестицій, проведення детінізації економіки, розширенню бази оподаткування та багатьох інших стимулюючих розвиток економіки факторів.

Аналіз останніх досліджень та публікацій. Дослідження різних податкових моделей, дозволило звернути увагу на механізм формування податку на прибуток Нігерії, який у зв’язку із рядом податкових реформ значно знизили інвестиційних клімат в країні [1], які були запроваджені до 1992 року. Після 1992 року, відбулись зміни в законодавстві, які спричинили до зменшення податкового тиску, i, як наслідок інвестиції в країну збільшились [2]. Загалом, дослідження залежності інвестиційного клімату з рівнем податного навантаження показали такі економічні зміни в країні [3], [4], [5]:

Починаючи з 1993 року, після зменшення корпоративного податку на прибуток $340 \%$ до 35\% в країні з'явилась інвестиційна надбавка отримання податкових пільг, створено податкові кредити для дрібних фермерів у сільській місцевості. Це спричинило збільшення ділової активності та надходження до бюджету податків.

Після 1996 року, також було зменшення податкової ставки на прибуток підприємств з 35\% до 30 \%. Зменшено податкові ставки для підприємств, що

займаються науково-дослідною та дослідно-конструкторською діяльністю на

20 \%. Повністю скасовано податок для підприємств, які займаються експортом протягом перших трьох років роботи, постачальникам матеріалів для підприємств, які займаються виробничою діяльністю для експорту, видобутком твердих корисних копалин.

Введено податкові канікули для малих підприємств, що займаються виробничою діяльністю протягом перших п'яти років роботи повністю орієнтований на експорт.

1998 рік. Надається податкове послаблення для підприємств, які займаються утилізацією газу на термін не менше 3 років, але не більше 5 років

1999 рік. Спрощується система оподаткування для підприємств, що займаються видобутком газу, до 35\%. 
У 2007 році спрощується оподаткування підприємств, які займаються страховим бізнесом, вирощуванням рослин, наданням телефонних послуг 3 метою ведення бізнесу в сільській місцевості.

Зменшення ПДВ для підприємств сфери надання послуг в Китаї у 2012 р. призвело до покращення податкової реформи. В результаті було отримано покращення умов підприємницької діяльності для дрібних підприємців [6].

Дотримуючись пропозицій Європейської комісії для $Є C$ про Загальну Консолідовану Базу Корпоративного Оподаткування (СССТВ), дослідники Spengel, C., Ortmann-Babel, M., Zinn 2012 р. провели аналіз впливу ряду пропозицій щодо податкового стимулювання малого бізнесу, на податкове навантаження держав членів. В результаті встановлено, що податкове навантаження в цілому не змінилося, проте було виявлено ряд позитивних аспектів саме для малого бізнесу [7]. Так, зафіксовано збільшення динаміки виникнення нових суб'єктів господарювання у цей період. Проте дослідження в цьому напряму, однозначно не вказують лише на позитивні сторони таких нововведень. Наприклад, Бельгія отримала збільшення податкового навантаження за рахунок скорочення державними програм на стимулювання податкових канікул [8].

Андерсон, Дж. Ф. у 2013 р., досліджуючи з 1979 по 2003 рр. в США вплив податкових реформ на податкове навантаження 3 використанням середньої податкової ставки, як показника податкового навантаження платників податків фізичних осіб, показав, що послідовне зниження податкового навантаження для всіх груп доходів, що дало позитивний ефект для розвитку малого бізнесу [9].

Позитивні аспекти оптимізації податкового навантаження було зафіксовано i серед вітчизняних вчених. Так, С. Аксюков провів порівняння показників податкового навантаження $з$ показниками соціально-економічного розвитку ряду світових країн. В результаті, було встановлено залежність між рівнем податкового навантаження та рівнем економічного розвитку. Занадто високе податкове навантаження, не сприяє розвитку економічного потенціалу країни [10 ].

Таким чином, аналіз літератури дав можливість встановити, як позитивні аспекти у сфері податкового навантаження так і негативні. В контексті податкової безпеки їх можна розцінювати не лише у відповідності до динаміки надходжень до бюджету, а й як зміни ділової активності бізнесу. Тому, розглядаючи процеси оптимізації податкових відносин, слід звернути увагу не лише на заходи 3 отримання податків, виведення їх $з$ тіні, а на можливості для бізнесу та притоку інвестицій.

Мета статті. На прикладі міжнародного та вітчизняного досвіду застосування податкових важелів для покращення фіскальної політики, показати можливості збільшення рівня податкової безпеки країни, шляхом оптимізації податкового навантаження, створення гнучкої системи оподаткування, інформаційного забезпечення податкових органів для збільшення ефективності управлінських рішень, представивши рекомендації для впровадження таких заходів в державному управлінні.

Виклад основного матеріалу. Теоретичні основи податкової безпеки беруть свій початок із державної безпеки. Це говорить про те, що податкова безпека, $\epsilon$ складовою державної безпеки, контекстів її економічного формулювання. 
Таким чином, в загальній структурі державної безпеки податкову безпеку можна представити наступним чином (мал. 1). Переважна більшість дослідників із такою думкою погоджується [11, с. 84], [12, с. 36], [13, с. 15], [14, с. 24], [15, с. 9].

Та незважаючи на розуміння податкової безпеки, як складової національної безпеки, що характеризує ефективність економіки шляхом оптимізації взаємовідносин держави із бізнесом та громадянами, слід відзначити i перспективний напрям подальших інвестицій в стратегічні сфери вітчизняної економіки.

3 погляду на досліджений досвід Нігерії, зменшення податкового навантаження на підприємства, діяльність яких представляє інтерес для держави, можна сказати, що саме податкова безпека відіграє ключову роль у формуванні ефективної та направленої на розвиток потрібних державі економічних сфер діяльності.

Таким чином, рівень податкової безпеки залежить від заходів фіскальної політики яка направлена на розвиток інноваційних підприємств екологічної сфери, військових підприємств, продовольчих компаній, вітчизняних IT компаній.

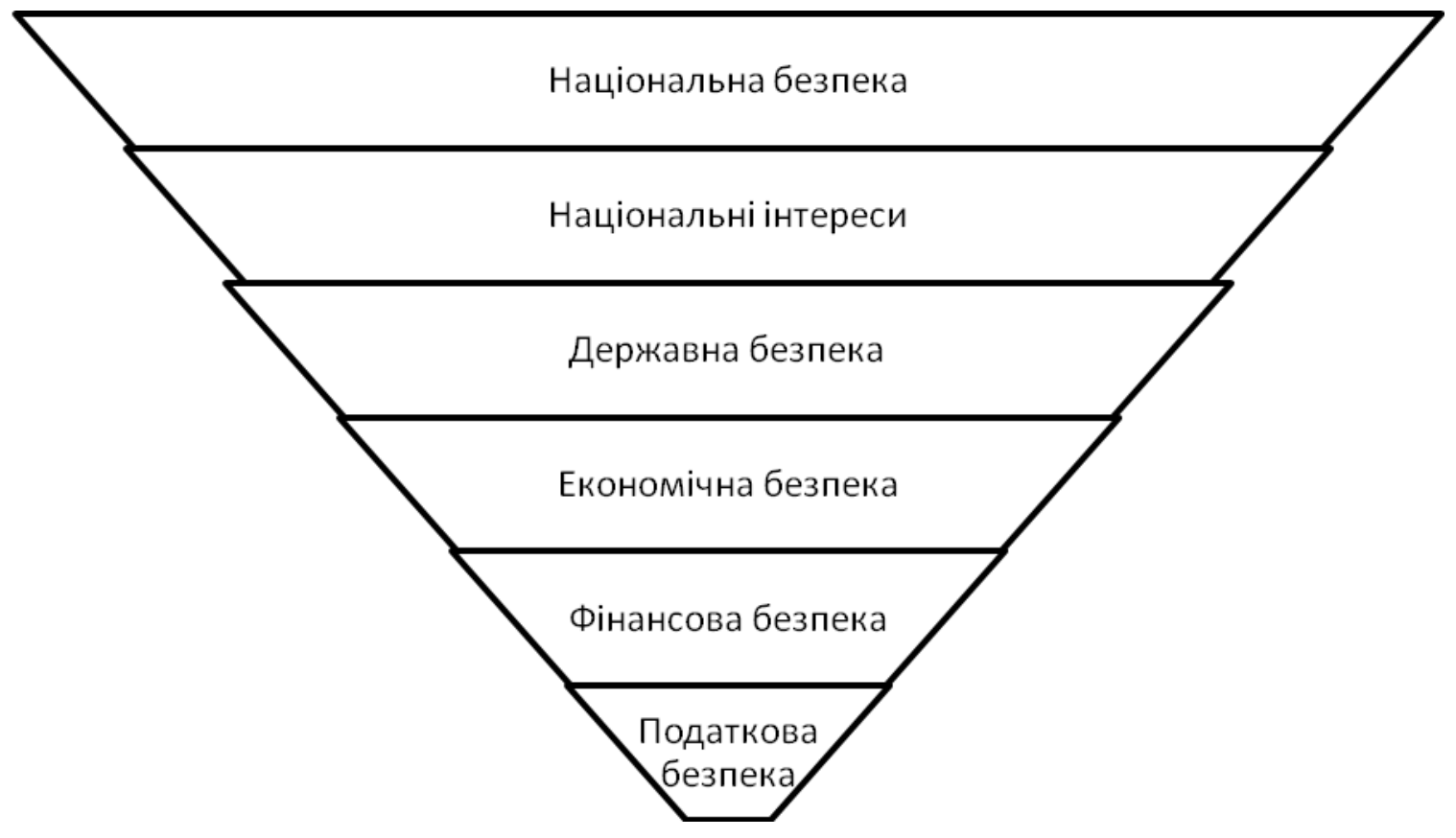

Мал. 1 Місие податкової безпеки в системі національної безпеки

В такому випадку держава виступає, як інвестор, який знає, як залучити інвестиції, які потім, через деякий час дадуть можливість отримати державі збільшення прибутку не лише за рахунок збільшення податкових надходжень, а й $\mathrm{i}$ за рахунок інвестування в реальний сектор економіки.

Для цього потрібен ефективний прогноз, який дозволить отримати економічне обгрунтування зменшення податкового навантаження на ту, чи іншу сферу. Для цього потрібно спочатку визначити загальний рівень податкової безпеки. 
Проблемам визначення рівня податкової безпеки присвячено багато наукових праць, основна части яких спрямована на встановлення критерію оптимальності податкового навантаження та рівня економічного зростання.

Так, наприклад I. Подік запропонував систему показників, які можуть бути застосовані при встановленні рівня податкової безпеки, а саме [16]:

1. рівень загального податкового навантаження (Рзп);

2. рівень тінізації економіки (Рте);

3. рівень відповідальності за сплату податків (Рв);

4. коефіцієнт результативності (Кр);

5. адміністрування податкових надходжень (Апн);

6. рівень податкового боргу платників податків (Рпб);

7. коефіцієнт еластичності (Ке);

8. коефіцієнт ефективності роботи фіскальних органів (Кефс);

Разом з тим автор дає визначення таких показників та їх обмеження, що можу бути представлено у вигляді системи рівнянь:

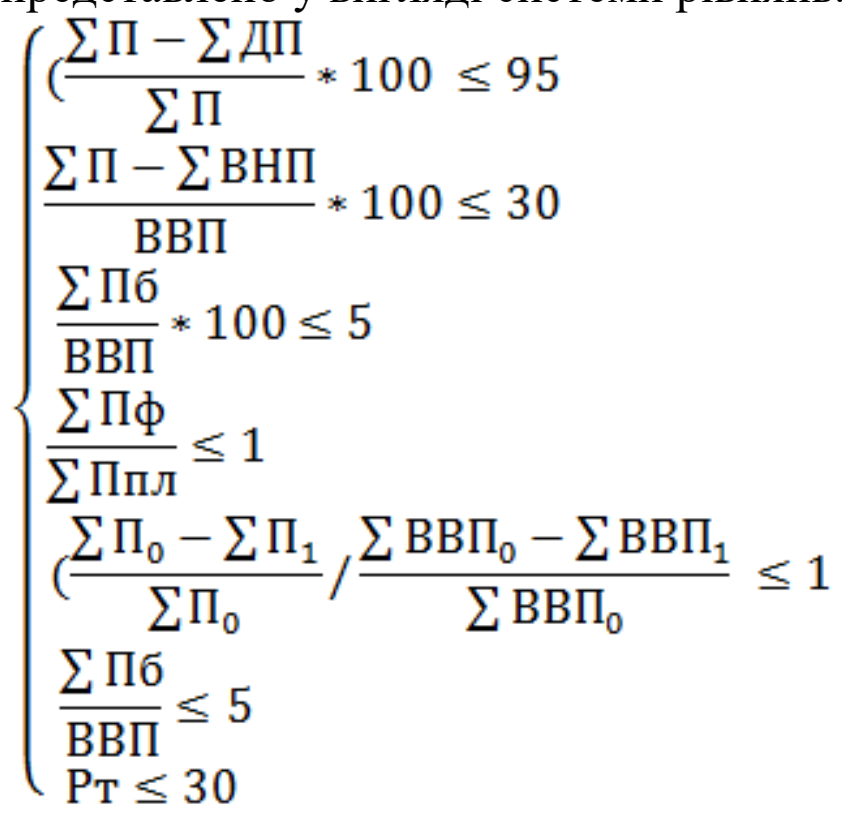

де:

П - податкові надходження до зведеного бюджету України; фондів;

ДП- сума коштів додатково нарахованих до бюджетів та державних цільових

ВНП- власні надходження Пенсійного фонду;

ВВП - валовий внутрішній продукт;

Пб - податковий борг з податкових надходжень, зборів та платежів;

Пф - фактичні податкові надходження до зведеного бюджету;

Ппл - планові податкові надходження зведеного бюджету;

$\Pi_{0}, \Pi_{1}$ - податкові надходження до зведеного бюджету;

за попередній та поточний періоди;

$\mathrm{BBП}_{0}, \mathrm{BBП}_{1}$ - обсяг валового внутрішнього продукту за попередній та звітні періоди. 
За таких умов загальний рівень податкової безпеки може бути обчислений у вигляді інтегрального показника податкової безпеки:

$$
\text { ІПб }=\frac{\sum_{i=1}^{n} P_{i}}{P_{n}}=\frac{\text { Рзп }+ \text { Рте }+ \text { Рв }+ \text { Кр }+ \text { Апн }+ \text { Рпб }+ \text { Ке }+ \text { Кефc }}{8}, \text { max } \rightarrow 167
$$

Таким чином, можливість встановити рівень податкової безпеки для певного сегменту державного управління є цілком реальною задачею. Інше питання, це прогнозування такої безпеки, де мають були застосовані адекватні моделі не лише для самого стану захищеності того чи іншого сектору економіки, а й для встановлення рівня економічної ефективності підприємств відповідної галузі. Разом з тим такі дані треба десь брати, що на нашу думку вимагає єдиної інформаційно-аналітичної системи, де, як розрахунок інтегрального показника податкової безпеки, так i ii інші характеристики можна було б отримати iз доступних засобів соціальних та комунікаційних мереж.

Нами було розроблено прототип такої платформи, де існує можливість розрахувати зазначений у статті інтегральний показник податкової безпеки 3 одного боку, та отримати статистику таких розрахунків, з іншого, що в цілому дасть можливість збирати статистичні дані та аналізувати їх на рівні часових рядів, накопичувати інформаційну базу та візуалізувати отримані дані [17].

Висновки. Переважна більшість країн, що розвиваються, спрямовують податкові послаблення для створення належного інвестиційного клімату, підтримки окремих, стратегічних для країни, галузей економіки, i, навіть окремих видів економічної діяльності. Такі заходи можна назвати оптимізаційними для національної безпеки. Однією із складових якої, виступає податкова безпека. I саме вона, відіграє ключову роль у створенні таких умов, коли бізнес буде ефективно розширюватись і держава матиме можливість збільшити економічний потенціал.

Усе це, вимагає потужної інформаційно-аналітичної роботи, яка дасть можливість визначити реальний рівень допустимого податкового навантаження, у відповідності до виду економічної діяльності, оцінити загальний рівень податкової безпеки та створити відкриту платформу для взаємодії бізнесу та держави.

\section{Jimepamypa:}

1. Odusola, A. (2006) Tax Policy Reforms in Nigeria. Research Paper No. 2006/3, United Nations University, World Institute of Development Economics Research.

2. Federal Inland Revenue Service (2012) A Comprehensive Tax History of Nigeria. Safari Books Ltd., Ibadan.

3. Salaudeen, Y. M., \& Atoyebi, T. A. (2018). Tax Burden Implication of Tax Reform. Open Journal of Business and Management, 6(3), 761-777.

4. Nworgu, I.A., Herbert, W. E. and Onyilo, F. (2016) A Longitudinal Assessment of Tax Reforms and National Income in Nigeria 1971-2014. International Journal of Economics and Finance, 8, 43-52. https://doi.org/10.5539/ijef.v8n8p43

5. Oti, P.A. and Odey, F.I. (2016) Tax Reform and Revenue Trends in Nigeria: The Dyadic Interact. Research Journal of Finance and Accounting, 7, 84-92.

6. Fang, H., Bao, Y. and Zhang, J. (2017) Asymmetric Reform Bonus: The Impact of VAT Pilot Programme on China's Corporate Tax Burden. China Economic Review, 46, 17-34. https://doi.org\10.1016lj.chieco.2017.02.003 
7. Spengel, C., Ortmann-Babel, M., Zinn, B. and Matenaer, S. (2012) A Common Corporate Tax Base for Europe: An Impact Assessment of Draft Council Directive on a CC@TB. World Tax Journal, 4, 185-221.

8. Roggeman, A., Verleyen, I., Van Cauwenberge, P. and Coppen, C. (2014) Impact of a Common Corporate Tax Base on the Effective Tax Burden in Belgium. Journal of Business, Economics and Management, 15, 530-543. https://doi.org/10.3846/16111699.2013.807869

9. Anderson, J.E. (2013) US Tax Acts and Their Effect on Average Tax Rates. Applied Economic Letters, 20, 131-134. https://doi.org/10.1080/13504851.2012.684781

10. Аксюков C. M. (2016) Оптимізація податкової системи України на шляху до економічного розвитку. Державне управління: удосконалення та розвиток № 10, 2016, [Електронний ресурс], Режим доступу: http://www.dy.nayka.com.ua/?op=1\&z=1007\#

11. Баранецька О. Національні інтереси України в сфері фіскальної безпеки / O. Баранецька, В. Мартинюк // Наука молода. - 2008. - № 9. - С. 83-87.

12. Іщенко В.В. Податкова складова фінансової безпеки держави / В.В. Іщенко // Вісник економіки транспорту і промисловості. - 2012. - № 37. - С.35-40.

13. Цвилий-Букланова А.А. Налоговий контроль в системе обеспечения налоговой безопасности государства : автореф. дис. ... канд. юр. наук. : 12. 00. 14 / А.А. Цвілій-Букланова. Челябинск, 2011. - 32 с.

14. Темовеева І.Ю. Налоговая безопасность государства, бизнеса и общества: концепция і методология: автореф. дис. ... док. ек. наук. : 12. 00. 14 / І.Ю. Темовеева. - М., 2011. -53 с.

15. Іванов Ю.Б. Податкова безпека: сутність та умови забезпечення / Ю.Б. Іванов, Ю.В. Бережна// Економіка розвитку. - 2010. - № 2(54). - С. 9-11.

16. Подік I. I. Оцінювання сучасного стану податкової безпеки України. Економіка та держава. 2017. № 4. С. 46-51.

17. Автоматизована система оцінювання рівня податкової безпеки, [Електронний ресурс], Режим доступу: http://lector.pythonanywhere.com/

\section{References:}

1. Odusola, A. (2006). Tax Policy Reforms in Nigeria. Research Paper No. 2006/3. United Nations University. World Institute of Development Economics Research [in English].

2. Okauru, I.O. (2012). A Comprehensive Tax History of Nigeria. Ibadan: Safari Books Ltd. [in English].

3. Salaudeen, Y.M., \& Atoyebi, T.A. (2018). Tax Burden Implication of Tax Reform. Open Journal of Business and Management, 6(3), 761-777 [in English].

4. Nworgu, I.A., Herbert, W.E. and Onyilo, F. (2016). A Longitudinal Assessment of Tax Reforms and National Income in Nigeria 1971-2014. International Journal of Economics and Finance, 8, 43-52. Retrieved from https://doi.org/10.5539/ijef.v8n8p43 [in English].

5. Oti, P.A. \& Odey, F.I. (2016). Tax Reform and Revenue Trends in Nigeria: The Dyadic Interact. Research Journal of Finance and Accounting, 7, 84-92 [in English].

6. Fang, H., Bao, Y. \& Zhang, J. (2017). Asymmetric Reform Bonus: The Impact of VAT Pilot Programme on China's Corporate Tax Burden. China Economic Review, 46, 17-34. Retrieved from https://doi.org 1 10.1016lj.chieco.2017.02.003 [in English].

7. Spengel, C., Ortmann-Babel, M., Zinn, B. \& Matenaer, S. (2012). A Common Corporate Tax Base for Europe: An Impact Assessment of Draft Council Directive on a CC@TB. World Tax Journal, 4, 185-221 [in English].

8. Roggeman, A., Verleyen, I., Van Cauwenberge, P. \& Coppen, C. (2014). Impact of a Common Corporate Tax Base on the Effective Tax Burden in Belgium. Journal of Business, Economics and Management, 15, 530-543. Retrieved from https://doi.org/10.3846/16111699.2013.807869 [in English].

9. Anderson, J.E. (2013). US Tax Acts and Their Effect on Average Tax Rates. Applied Economic Letters, 20, 131-134. Retrieved from https://doi.org/10.1080/13504851.2012.684781 [in English]. 
10. Aksiukov, S.M. (2016). Optymizatsiia podatkovoi systemy Ukrainy na shliakhu do ekonomichnoho rozvytku [Optimization of the tax system of Ukraine on the way to economic development]. Derzhavne upravlinnia: udoskonalennia ta rozvytok - Public administration: improvement and development, 10. Retrieved from http://www.dy.nayka.com.ua/?op=1\&z=1007\# [in English].

11. Baranetska, O., Martyniuk, V. (2008). Natsionalni interesy Ukrainy v sferi fiskalnoi bezpeky [National interests of Ukraine in the field of fiscal security]. Nauka moloda - Young Science, 9, 83-87 [in Ukrainian].

12. Ishchenko, V.V. (2012). Podatkova skladova finansovoi bezpeky derzhavy [Tax component of the financial security of the state]. Visnyk ekonomiky transportu $i$ promyslovosti - Bulletin of Transport Economics and Industry, 37, 35-40 [in Ukrainian].

13. Tsvylyi-Buklanova, A.A. (2011). Nalohovyi kontrol v systeme obespechenyia nalohovoi bezopasnosty hosudarstva [Tax control in the system of ensuring the tax security of the state]. Extended abstract of candidate's thesis. Cheliabynsk [in Russian].

14. Timofeeva, I.Yu. (2011). Nalogovaya bezopasnost gosudarstva, biznesa i obshchestva: kontseptsiya i metodologiya [Tax security of the state, business and society: concept and methodology]. Extended abstract of Doctor's thesis. Moscow [in Russian].

15. Ivanov, Yu.B., Berezhna, Yu.V. (2010). Podatkova bezpeka: sutnist ta umovy zabezpechennia [Tax security: essence and conditions of provision]. Ekonomika rozvytku - Economics of Development, 2(54), 9-11 [in Ukrainian].

16. Podik, I.I. (2017). Otsiniuvannia suchasnoho stanu podatkovoi bezpeky Ukrainy [Assessment of the current state of tax security of Ukraine]. Ekonomika ta derzhava - Economy and state, 4, 46-51 [in Ukrainian].

17. Avtomatyzovana systema otsiniuvannia rivnia podatkovoi bezpeky [Automated system for assessing the level of tax security]. lector.pythonanywhere.com. Retrieved from http://lector.pythonanywhere.com/ [in Ukrainian]. 